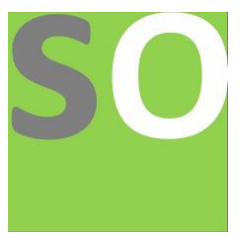

Article title: Latin America: Reduced S\&T Investment Puts Sustainable Development at Risk Authors: Pablo Bolaños-Villegas[1], Franco Cabrerizo [2], Federico Brown[3], Patricia Zancan[4], John F. Barrera[5], Pablo A. González-Muñoz[6], Hernán Grecco[7], Alexis Kalergis[8], Andrea Paula-Lima[9], Ronald Vargas-Balda[10], Rolando Gittens[11], Sandra López Vergès[12], Christian Wilson[13]

Affiliations: fabio baudrit agricultural research station, university of costa rica, la garita de alajuela, alajuela 20102, costa rica and jardín botánico lankester, universidad de costa rica, p.o. box 302-7050, cartago, costa rica.[1], chascomús institute of technology (intech, conicet, unsam). av. intendente marino km 8.2, cc 164, c.p. 7130, chascomús, buenos aires, argentina.[2], department of zoology, institute of biosciences, university of sao paulo, rua do matão, travessa 14, n.101, cidade universitaria, sao paulo sp. cep 05508-900, brazil[3], laboratory of molecular oncology, department of pharmaceutical biotechnology, faculty of pharmacy, federal university of rio de janeiro, ufrj, av. carlos chagas filho 373, ccs, bloco b subsolo sala 19, ilha do fundacao, rio de janeiro, rj 21941-902, brazil[4], optics and photonics group, institute of physics, faculty of exact and natural sciences, university of antioquia udea, calle 70 no. 52-21, medellín, colombia[5], department of molecular genetics and microbiology, faculty of biological sciences, pontifical catholic university of chile, av. portugal 49 , edificio 210 , piso 6 , santiago 8330025 a, chile[6], laboratory of quantic electronics, faculty of natural and exact sciences, university of buenos aires, pabellón i, ciudad universitaria, 1428 buenos aires, argentina[7], millenium institute on immunology and immunotherapy, departamento de genética molecular y microbiología, facultad de ciencias biológicas. departamento de endocrinología, facultad de medicina. pontificia universidad católica de chile[8], faculty of dentistry, university of chile, calle sergio livingstone pohlhammer 943, independencia santiago, santiago 8380-492, chile.[9], electrochemistry laboratory, chemistry department, universidad simón bolívar, caracas, venezuela[10], instituto de investigaciones científicas y servicios de alta tecnología (indicasat-aip), panama city, panama.[11], department of research in virology and biotechnology, gorgas memorial institute of health studies, panama city, panama.[12], laboratory of biochemistry, faculty of chemical and pharmaceutical sciences, university of chile, santos dumont 964, independencia, santiago 8380494, chile.[13]

Orcid ids: 0000-0003-1729-0561[1], 0000-0002-0286-3956[11], 0000-0002-1106-8479[12]

Contact e-mail: pablo.bolanosvillegas@ucr.ac.cr

License information: This work has been published open access under Creative Commons Attribution License http://creativecommons.org/licenses/by/4.0/, which permits unrestricted use, distribution, and reproduction in any medium, provided the original work is properly cited. Conditions, terms of use and publishing policy can be found at https://www.scienceopen.com/.

Preprint statement: This article is a preprint and has not been peer-reviewed, under consideration and submitted to ScienceOpen Preprints for open peer review.

Funder: Vicerrectoria de Investigación/Universidad de Costa Rica, Sistema Nacional de Investigación (SNI/SENACYT) of Panama.

DOI: 10.14293/S2199-1006.1.SOR-.PPBPKUJ.v3

Preprint first posted online: 26 January 2020

Keywords: Latin America, Science, Sustainable Development, Fiscal Austerity, Environmental Degradation, Social Turmoil 
Title: ScienceOpen Preprints

Publisher: ScienceOpen

ScienceOPEN.com

Publication date (Electronic preprint): 27 January 2020

ID: 10.14293/S2199-1006.1.SOR-.PPBPKUJ.v3

\section{Title: Latin America: Reduced S\&T Investment Puts Sustainable Development at Risk}

Authors: P. Bolaños-Villegas ${ }^{1,2 * \dagger}$, F.M. Cabrerizo ${ }^{3 * \dagger}+$ F. D. Brown ${ }^{4 * \dagger} \uparrow$, P. Zancan ${ }^{5} \uparrow$, J.F. Barrera-Ramírez ${ }^{6}$, P.A. González-Muñoz ${ }^{7}$, H.E. Grecco ${ }^{8}$, A.M. Kalergis ${ }^{9}$, A.C. Paula-Lima ${ }^{10}$, R.E. Vargas-Balda ${ }^{11}$, R.A. Gittens ${ }^{12}$, S. López-Vergès ${ }^{13}$, C.A.M. Wilson ${ }^{14}$.

\section{Word count: 2642}

\section{Affiliations:}

${ }^{1}$ Fabio Baudrit Agricultural Research Station, University of Costa Rica, La Garita de Alajuela, Alajuela 20102, Costa Rica.

${ }^{2}$ Jardín Botánico Lankester, Universidad de Costa Rica, P.O. Box 302-7050, Cartago, Costa Rica.

${ }^{3}$ Chascomús Institute of Technology (INTECH, CONICET, UNSAM). Av. Intendente Marino Km 8.2, CC 164, C.P. 7130, Chascomús, Buenos Aires, Argentina.

${ }^{4}$ Department of Zoology, Institute of Biosciences, University of Sao Paulo, Rua do Matão, Travessa 14, n.101, Cidade Universitaria, Sao Paulo SP. CEP 05508-900, Brazil.

${ }^{5}$ Laboratory of Molecular Oncology, Department of Pharmaceutical Biotechnology, Faculty of Pharmacy, Federal University of Rio de Janeiro, UFRJ, Av. Carlos Chagas Filho 373, CCS, Bloco B Subsolo Sala 19, Ilha do Fundacao, Rio de Janeiro, RJ 21941-902, Brazil.

${ }^{6}$ Optics and Photonic's Group, Institute of Physics, Faculty of Exact and Natural Sciences, University of Antioquia UdeA, Calle 70 No. 52-21, Medellín, Colombia.

${ }^{7}$ Department of Molecular Genetics and Microbiology, Faculty of Biological Sciences, Pontifical Catholic University of Chile, Av. Portugal 49, Edificio 210, piso 6, Santiago 8330025A, Chile.

${ }^{8}$ Laboratory of Quantic Electronics, Faculty of Natural and Exact Sciences, University of Buenos Aires, Pabellón I, Ciudad Universitaria, 1428 Buenos Aires, Argentina.

${ }^{9}$ Millenium Institute on Immunology and Immunotherapy, Departamento de Genética Molecular y Microbiología, Facultad de Ciencias Biológicas. Departamento de Endocrinología, Facultad de Medicina. Pontificia Universidad Católica de Chile.

${ }^{10}$ Faculty of Dentistry, University of Chile, Calle Sergio Livingstone Pohlhammer 943, Independencia Santiago, Santiago 8380-492, Chile.

${ }^{11}$ Electrochemistry Laboratory, Chemistry Department, Universidad Simón Bolívar, Caracas, Venezuela. 
${ }^{12}$ Instituto de Investigaciones Científicas y Servicios de Alta Tecnología (INDICASAT-AIP), Panama City, Panama.

${ }^{13}$ Department of Research in Virology and Biotechnology, Gorgas Memorial Institute of Health Studies, Panama City, Panama.

${ }^{14}$ Laboratory of Biochemistry, Faculty of Chemical and Pharmaceutical Sciences, University of Chile, Santos Dumont 964, Independencia, Santiago 8380494, Chile.

*Correspondence to: p.bolanosvillegas@ucr.ac.cr, fcabrerizo@intech.gov.ar, and fdbrown@usp.br.

$\dagger$ Equal contributions.

Abstract: Latin America is home to more than 600 million people and has considerable natural and human resources. However, investment in science and technology (S\&T) lags far behind that in developed countries. This gap represents a barrier to the development of economies based on knowledge and hampers the region's ability to tackle environmental and social problems. This lack of investment is evident in the extreme case of Venezuela, where much of the science workforce has fled economic chaos, but also in every Latin American country, including science powers such as Brazil and Argentina, where federal budgets in science, technology and education have been drastically reduced in recent years. Investments in S\&T foster cooperation, commerce and good will and enhance resilience in the face of environmental and social turmoil. Therefore, scientists must start to actively engage governments and encourage long-term spending in S\&T to support the development of Latin American societies. Word count: 150

Keywords: Latin America, Science, Sustainable Development, Fiscal Austerity, Environmental Degradation, Social Turmoil.

\section{Main Text:}

In Latin America and the Caribbean, education, science and technology (S\&T) have rarely taken the place they deserve as indispensable tools to achieve long-term sustainable development and to advance the overall quality of people's lives. This could explain why while the region represents 8.6 percent of the world's population, only 2.5 percent of all scientists come from that Latin America (Inter-American Development Bank, 2007) The topic of S\&T may be mentioned briefly during presidential campaigns, but most countries lack policies to stimulate science-driven ScienceOpen, 27 January 2020, ID: 10.14293/S2199-1006.1.SOR-.PPBPKUJ.v3 
development. As in many developing countries, an underlying bias in Latin America holds that S\&T are a frivolous expense that is unconnected to development. Political and economic chaos in Venezuela has decimated the science sector; in other countries, an ideological shift to conservatism coupled with cycles of boom and bust have resulted in the current period of generalized fiscal austerity. But we know that strong investment in S\&T and development is a trait of the successful and newly industrialized economies in Asia and in established powerhouses such as Japan, Germany and the United States (The World Bank, 2016), which invest 2.5\% of their GDP, on average, in S\&T (The World Bank,2016). South Korea is now a fully industrialized country and a leader in Science and Technology (The World Bank, 2016).

Moreover, in order to have a strong research system that fosters creativeness and innovation, the S\&T environment in Latin America needs to tackle inequality and lack of diversity in science, as few scientists come from either low-income households, or African and indigenous backgrounds (Gevin, 2019). Clear policies are also needed to promote gender equity in the region: even though women are 46 percent of all researchers in Latin America, one of the highest percentages in the world, they still receive low salaries, and are not promoted to decision-making positions (Inter-American Development Bank, 2007; Senacyt, 2018).

In Argentina, past President Macri slashed research investment from $0.62 \%$ of GDP in 2015 to $\sim 0.3 \%$ (estimated value since no official numbers are available) in 2018 , with a projected reduction of tens of millions of dollars to only $0.25 \%$ for 2019 (Fig. 1). Budget cuts have affected the main national S\&T bodies, namely the National Scientific and Technical Research Council (CONICET), national universities, and scientific organizations such as the Industrial Technology Institute, Atomic Energy Commission, Institute of Agricultural Technology, Space Activities Commission and the Argentinian National Company of Satellite and Nuclear Reactors (Noticias Magazine, 2018) (Fig. 3). In many cases, these cuts led to the closure of development and innovation programs, including flagship scientific projects such as the Argentinian Satellite Program and Argentinian Nuclear Power Program. A decrease in the number of projects financed for S\&T activities, together with the depreciation of the national currency, have resulted in subsidies that are insufficient to sustain advanced scientific activities. The continuity of planned research agendas and research groups has been placed at serious risk. The few subsidies ScienceOpen, 27 January 2020, ID: 10.14293/S2199-1006.1.SOR-.PPBPKUJ.v3 
researchers have access to now reach maximum US dollar values of $\sim 10,000$ per year for entire research teams. Likewise, programs that were funded with international cooperation in mind have been interrupted, which has resulted in the discontinuity of ongoing projects and acute brain drain. Of note, budget cuts in education and S\&T were accompanied by increased spending on defence (The Official Newsletter of the Argentine Republic, 2018; El Tiempo Newspaper, 2018).

In the case of Brazil, cuts to research by Presidents Temer and Bolsonaro have reached $50 \%$ or more since 2016 , with loses again mounting to hundreds of millions of dollars. These cuts put at risk Brazil's significant advances across a range of fields. Particularly noteworthy in recent years has been the development of oceanographic technologies for exploring and extracting deepsea oil and natural gas, transforming Brazil into one of the largest oil and gas producers in the world. The development of a local aeronautic industry due to efforts by the Technological Institute of Aeronautics and EMBRAER (Brazil's aircraft manufacturing company) made Brazil an important player in the aircraft production industry. Other important examples are the development of a strong agricultural sector, especially in soybeans for export to China, and the construction of Sirius, a $4^{\text {th }}$-generation particle accelerator (Fig. 3). In biomedical research, important discoveries have been made to combat HIV and Zika virus. This legacy is now in danger (Brazilian Society for the Advancement of Science, 2018). In 2018, the National Council for Scientific and Technological Development (CNPq) operated with a budget deficit of R \$85 million (about \$20 million); nearly 5,000 research projects that had already been approved could not be funded (National Congress of Brazil, 2018). This situation led to a 75\% reduction in the number of scholarships (National Congress of Brazil, 2018). The general budget of CNPq was expected to be further decreased (14\%) (National Congress of Brazil, 2018). Additionally, the acclaimed program Science without Borders $(\mathrm{CsF})$, which invested almost $\mathrm{R} \$ 1.9$ billion ( $\$ 0.4$ billion) per year for seven consecutive years to develop collaborations with well-established groups abroad, was abolished (National Congress of Brazil, 2018). In March 2019, the Bolsonaro government announced a new $42 \%$ budget cut for the Ministry of Science and Communications, and a $30 \%$ cut to all federal universities (de Oliveira, 2019). Although final numbers for the year 2019 are not yet available, it is public that the situation for universities already worsened dramatically, surpassing the most pessimistic forecasts. All of these cuts have resulted in an extremely uncertain research scenario that resulted in the abandonment of researchers and of research lines relevant to the ScienceOpen, 27 January 2020, ID: 10.14293/S2199-1006.1.SOR-.PPBPKUJ.v3 
country's development (de Oliveira, 2019). To make matters worse, relaxation of environmental regulations and indigenous reserve protections during the Bolsonaro regime have resulted in an increase of deforestation rates ( $>50 \%$ than last year) and forest fires ( $>80 \%$ than last year) in 2019 , threatening conservation efforts in the world's most biodiverse country (Escobar, 2019; Gibbens, 2019).

When considering the eradication of poverty, one of the Sustainable Development Goals (SDGs) proposed by the UN, Brazil is ranked 79 $/ 189$ in Human Development (HDI), with 13.2 million people living in extreme poverty. According to Oxfam, Brazil holds the second place in the world with the highest income concentration within the richest 1\% (OXFAM, 2019). However, the current Brazilian government has cut the budget of social programs for 2020, reducing resources to the poorest communities and perhaps stunting human development for years to come.

In relation to agricultural sustainability, most agricultural activities are threatened as the Amazon helps regulate regional climate via evapotranspiration, which directly affects regional rainfall (Spera et al., 2016).

Mexico's universities have greatly contributed to Earth sciences, physics, material sciences and electronics. One example is its famed National Laboratory of Genomics for Biodiversity (Langebio) (Fig. 3). Unfortunately, Mexico's federal government is currently facing a deficit and may resort to budget cuts to achieve a 1\% surplus for 2019 (Mexico News Daily, 2019). Mexico's national council for S\&T (CONACYT, in Spanish) has seen its budget cut by $6.5 \%$ (Mexico.com Newspaper, 2018). Cuts to salaries at its largest research universities have been announced despite President López-Obrador's pledge to support S\&T (Mexico.com Newspaper, 2018). Approximately 100000 university employees went on strike during October 2019 to protest the bankruptcy imposed by the federal government on nine state universities, which means that wages are not being paid and that some universities will close by the end of the year (Lobo, 2019). Though Mexico is a relatively wealthy middle-income economy, industrial productivity remains low.

Chile has made great contributions to Earth sciences, mathematics, physics, astrophysics, biology and biomedicine. Nonetheless, it has historically invested only about $0.4 \%$ of its GDP in 
S\&T (The World Bank, 2016) (Fig. 1). This amount is mostly invested by the state, and research is mostly carried out in universities (OECD, 2018). The Ministry of Science, Technology, Knowledge and Innovation was created only recently (National Library of Congress of Chile, 2018). Despite positive expectations regarding its creation and the establishment of long-term policies for S\&T in the country, to be successful these will require a significant increase in public investment in science. However, there is also the risk that the ministry might reduce the effective budget for research grants given the administrative costs of running this new institution. Two of the main problems in Chile are the low rate of approval of scientific projects due to the strong increase in applicants and the lack of positions for young scientists at universities and research centres. Undoubtedly, this situation will jeopardize the development of scientific careers especially for young researchers, who face serious financing difficulties at the start of their careers. Regarding the current situation of social unrest, it is believed that a strong investment in science may facilitate the correction of social injustice, and help address other pressing problems such as water scarcity, desertification, and the accelerated ageing of its population (Hidalgo, 2019).

Colombia has developed scientific strengths in immunology, physics and environmental sciences. One example is its Optics and Photonics Laboratory at Antioquia University (Fig. 3). However, only $0.24 \%$ of Colombian GDP is invested in S\&T, 15 times lower than the OECD members average (The World Bank,2016). Colombian S\&T investment is only a fraction of Mexico’s (La República Newspaper, 2017). Compounding this problem, Colombia ranks last in education investment among Latin American countries, reaching only $10 \%$ to $20 \%$ of the investment by others in the region (El País Newspaper, 2017). Protests have intensified during 2019 as a response to poor funding to universities and proposed privatisation of pensions, reduction of the minimum wage for young people and an increase in energy tariffs (Franz and Gómez-Suárez, 2019).

Costa Rica has built the only nuclear fusion reactor in Central America (IAEA 2018) and its only medical cyclotron (Semanario Universidad Newspaper, 2019) (Fig. 3). It has also developed its own technologies for antibody production and blood plasma storage (Semanario Universidad Newspaper, 2018). Nonetheless, only about $0.4-0.6 \%$ of its GDP is invested in S\&T (The World Bank, 2016) mainly through public universities (95\%) (OECD, 2018), in strong ScienceOpen, 27 January 2020, ID: 10.14293/S2199-1006.1.SOR-.PPBPKUJ.v3 
contrast to the nearly $2.5 \%$ GDP average investment by the 36 countries of the Organization for Economic Cooperation and Development (OECD) (OECD, 2018). Private spending in science is low even compared with other Latin American OECD countries, in which at least $30 \%$ of spending is private $(\mathrm{OECD}, 2018)$. But facing a budget deficit of $7 \%$, the current administration has cut the overall budget of public universities and is moving to cut university staff pay (La Nación Newspaper, 2019). The Constitutional Court has ruled that efforts to reduce spending on education are unconstitutional (Delfino, 2019).

Panama has been historically known research in biodiversity and tropical diseases, conducted mainly by the Smithsonian Tropical Research Institute, an US-institution based in Panama, and by the Gorgas Memorial Institute of Health Studies, first run by the US government but managed by Panama since 1990. The National Office for Research, Technology and Innovation (SENACYT in Spanish) was created in 1997, and its programs have allowed for an increase in the number of Ph.D. holders and in scientific publications. However, Panama has been spending less than $0.1-0.2 \%$ of its GDP in S\&T, a proportion far lower than that of Sub-Saharan countries (La Prensa Newspaper, 2019). This amount is mostly contributed by the government. It is believed that a strong increase in investment S\&T is required in order to tackle Alzheimer disease, ageing as well as neglected tropical diseases (La Prensa Newspaper, 2019). Newly elected President Cortizo has promised to increase the investment in S\&T to $1 \%$ of GDP within the next five years (La Estrella de Panamá, 27/03/2019), a situation unique in the whole continent.

For decades, Venezuela made significant contributions to medicine, chemistry, biology, petrochemical processing, physics, mathematics and various engineering disciplines. Today, overwhelmed by political and economic crisis, the country is struggling through one of the worst moments in its history (Fraser, 2016). The effects on science are profound: In 2014, Venezuela had an estimated 12,850 researchers; now only about 3,000 remain (Requena, 2016). This braindrain resulted in a strong decrease in scientific productivity $(>50 \%)$ according to figures from SCImago Journal \& Country Rank. With the ongoing economic and social collapse, an estimated $10 \%$ of the population left the country in 2018 , and many scientists have requested refugee status abroad. The development of local industries focused around food processing, and the manufacture of radiopharmaceuticals and blood-derived products, have stopped altogether. Poor funding ScienceOpen, 27 January 2020, ID: 10.14293/S2199-1006.1.SOR-.PPBPKUJ.v3 
(0.12\% of GDP as of 2016) (Requena, 2016), aggravated by hyperinflation and frequent blackouts, result in empty laboratories, deteriorating equipment and run-down infrastructure. Students and faculty are deserting the country. Venezuela's science sector is collapsing.

As for the rest of Latin America and the Caribbean, data are scarce. In Peru, there was no Internet access at all to scientific journals in 2016 (La República Newspaper, 2017). Peru only spends about $0.1 \%$ of its GDP in S\&T (UNESCO, 2015), and Dr. Gisella Orjeda, the former president of Peru's National Council of Science, has mentioned that poor resource allocation may have contributed to chronic and severe brain-drain (Bajak, 2019). Also located in South America, Ecuador is a country that spends $0.4 \%$ of its GDP in S\&T (UNESCO, 2015). In 2019, civil unrest caused by austerity measures agreed by President Moreno with the International Monetary Fund (IMF) seriously disrupted work at universities (Cozzarelli, 2019; Medina, 2019).

According to several sources, including UNESCO (Fig. 2), as of 2015 investment in S\&T as a percentage of GDP in Central America is as follows: Cuba (0.4), El Salvador (0.13), Nicaragua (0.11) (Fig. 3), Guatemala (0.03), Honduras (0.02) and Belize (no data) (The World Bank, 2016). In the poorest of these countries, science may remain stunted by pervasive violence, economic weakness, high inequality and massive emigration. Scientific cooperation within Central America and the Caribbean is extremely rare.

\section{Concluding remarks}

On average countries in Latin America and the Caribbean invest only $0.3 \%$ or less of their GDP in S\&T (Fig. 2). This investment is in clear contrast to countries with a high degree of human development, which invest close to $3 \%$ of their GDP in S\&T: Japan (3.2\%), Sweden (3.2\%), Denmark (2.9\%), Finland (2.8\%), Germany (2.9\%) and the United States $(2.7 \%)$ (The World Bank, 2016). In Asia countries such as South Korea, that were poor agricultural societies 50 years ago, spend close to 7\% (The World Bank, 2016). We believe that after years of uneven but encouraging progress, many governments in Latin America are now engaged in policies that are destructive to science, education, social advancement, the environment and gender inclusion. Gender exclusion in Latin America is particularly acute in engineering, and it is believed that at the current rate gender parity will be achieved in 150 years (López-Aguirre, 2019). Budget cuts to education and research in Latin America may perpetuate low productivity and stunted economic growth as the skills of future workers will not match the needs of advanced production systems. ScienceOpen, 27 January 2020, ID: 10.14293/S2199-1006.1.SOR-.PPBPKUJ.v3 
The region desperately needs to address medical, agricultural, energy and environmental issues, and these efforts require an increase in scientific investment, not the opposite. We also believe that low investment may lead to a weakening of regional cooperation networks, which are necessary for harmonious and integrated development, especially considering that bitter border and political disputes between countries are common. A concerted effort that transcends political ideologies is urgent.

Dr. Bernardo Houssay, an Argentinean Nobel Laureate in Medicine in 1947, advised that "rich countries are rich because they dedicate money to scientific-technological development, and poor countries continue to be poor because they do not. Science is not expensive, what is expensive is ignorance." In this context, we advocate a bold new vision: Our societies need to design new strategies for a sustained investment in S\&T that can lead to an improvement in regional innovation and cooperation. Without this investment, economic and social development will slow, societal turbulence will worsen (The Guardian, 2019), environmental degradation will be extreme, and we will not achieve the enormous potential of our countries and our people.

\section{References and Notes}

Bajak, A. (2019) 'What should Peru do to improve its sciences?', Nature, 576: S65-S67. < https://www.nature.com/articles/d41586-019-03844-2>.

Brazilian Society for the Advancement of Science (SBPC) (2018), Representatives of Brazilian research centres denounce a science policy crisis (translated from Portuguese) (Sao Paulo, pubd online May 2018) <http://portal.sbpcnet.org.br/noticias/representantes-do-cnpq-capes-e-finepdenunciam-grave-crise-nas-politicas-publicas-para-cti/>accessed 15 June 2019.

Cozzarelli, T. (2019), Mass protests in Ecuador force government to withdraw austerity measureswas more possible? (Brooklyn, NY; pubd online October 2019) < https://www.leftvoice.org/massprotests-in-ecuador-force-government-to-withdraw-austerity-measures-was-more-possible $>$ accessed 20 November 2019.

Delfino (2019), The constitutional court declares the 2020 budget "unconstitutional" for breaching investment goals in education (translated from Spanish) (San Jose; pubd December 2019), <https://delfino.cr/2019/12/sala-iv-declara-inconstitucional-presupuesto-2020-porincumplir-inversion-en-educacion $>$ accessed 3 January 2020.

de Oliveira, A. (2019) 'Brazil's budget cuts threaten more than 80,000 science scholarships', Nature, 7771:575-6 <https://www.nature.com/magazine-assets/d41586-019-02484-w/d41586019-02484-w.pdf>. 
El País Newspaper (2017), Colombia is the Latin American country that invests the least in education according to the OECD (translated from Spanish) (Cali; pubd September 2017), $<$ https://www.elpais.com.co/colombia/es-el-pais-latino-que-menos-invierte-en-educacion-segunla-ocde.html $>$ accessed 25 July 2019.

El Tiempo Newspaper (2018), The government hands out cash to taken from budget cuts to science, culture and education (translated from Spanish) (Buenos Aires; pubd online September 2018), <https://www.tiempoar.com.ar/nota/cambiemos-le-da-a-la-policia-la-plata-que-recorta-enciencia-cultura-y-educacion>accessed 3 July 2019.

Escobar, H. (2019) 'Brazilian president attacks deforestation data', Science, 365:419<https://science.sciencemag.org/content/365/6452/419>.

Franz, T., and Gómez-Suárez, A. (2019) Why is Colombia striking for change? (London; pubd online December 2019), <https://blogs.lse.ac.uk/latamcaribbean/2019/12/16/why-is-colombiastriking-for-change/> accessed 3 January 2020

Fraser, B. (2016) 'Science under siege: how Venezuela's economic crisis is affecting researchers', Nature, 535:336-7, <https://www.nature.com/news/science-under-siege-how-venezuela-seconomic-crisis-is-affecting-researchers-1.20261>.

Gevin, W. (2019) 'More indigenous and Latin American students are joining US graduate programmes, but overall diversity remains low', Nature, 576: 170, $<\underline{\text { https://www.nature.com/articles/d41586-019-03546-9 }>\text {. }}$

Gibbens, S. (2019) The Amazon forest is on fire at record rates, and deforestation is responsible for an environmental tragedy (translated from Portuguese) (Washington DC; pubd August 2019) $<$ https:/www.nationalgeographicbrasil.com/meio-ambiente/2019/08/tragedia-amazoniapegando-fogo-bolsonaro-recordes-desmatamento-fumaca-impacto $>$ accessed 22 August 2019.

Hidalgo, C. (2019), Dispatches from around the world, Chile: scholarship is key to equity (London, pubd December 2019), <https://www.nature.com/magazine-assets/d41586-019-03872y/d41586-019-03872-y.pdf $>$ accessed 3 January 2020.

IAEA (2018), Fusion energy in the $21^{\text {st }}$ century: status and the way forward (Vienna; pubd September 2018), <https://www.iaea.org/newscenter/news/fusion-energy-in-the-21st-centurystatus-and-the-way-forward $>$ accessed 15 October 2019.

Inter-American Development Bank (2007), Women on the challenges of being a scientist in Latin America and the Caribbean (Washington D.C., pubd January 2007), $<$ https:/www.iadb.org/en/news/webstories/2007-01-16/women-on-the-challenges-of-being-ascientist-in-latin-america-and-the-caribbean\%2C3564.html > accessed 4 January 2020.

La Estrella de Panamá Newspaper (2019), President Cortizo says he will boost the creation of technological companies (translated from Spanish) (Panama City; pubd March 2019) 
<https://www.laestrella.com.pa/nacional/politica/190327/cortizo-asegura-creacion-empresasimpulsara $>$ accessed 4 January 2020.

La Nación Newspaper (2019), The University of Costa Rica is not within the purview of the new tax plan, according to its lawyers (translated from Spanish) (San Jose; pubd January 2019), $<$ https://www.nacion.com/el-pais/educacion/ucr-exenta-de-aplicar-plan-fiscal-dicensus/2KCACM4NCVCV3AFSF2CPE4EXSI/story/> accessed 15 October 2019.

La Prensa Panama (2019), Investing on Science is essential for development (translated from Spanish)(Panama City; pubd April 2019), <https:/www.prensa.com/impresa/panorama/inversionciencias-esencial-avance-Britton 0 5284721535.html > accessed 3 January 2020

La República Newspaper (2017), Colombia's 2017 science budget is only 8\% that of Mexico (translated from Spanish)(Bogota; pubd September 2017), $<\underline{\text { https://www.larepublica.co/globoeconomia/el-presupuesto-para-ciencia-y-tecnologia-de- }}$ colombia-en-2017-es-8-el-de-mexico-2543519> accessed 25 July 2019.

Lobo, A. (2019), Mexico: 100,000 university workers strike as López Obrador's vows deeper austerity (Oak Park; pubd October 2019), < https://www.wsws.org/en/articles/2019/10/10/mexio10.html> accessed 3 January 2020.

López-Aguirre, C. (2019), 'Women in Latin American science: gender parity in the twenty-first century and prospects for a post-war Colombia', Tapuya, 2/1: 356-77, $<$ https://doi.org/10.1080/25729861.2019.1621538>.

Medina, E. (2019), Dispatches from around the world, Ecuador: food drive kept campus open (London, pubd December 2010), <https://www.nature.com/magazine-assets/d41586-019-03872y/d41586-019-03872-y.pdf $>$ accessed 3 January 2020.

Mexico News Daily (2019), Government to make more spending cuts as it seeks to avoid deficit: from republican austerity to Franciscan poverty (Mexico City; pubd online March 1999), $<$ https://mexiconewsdaily.com/news/government-to-make-more-spending-cuts/> accessed 15 June 2019.

Mexico.com Newspaper (2018), Budget cuts to the Mexican Council for Science and government universities stand in place (translated from Spanish) (Mexico City; pubd online July 1999), $<$ https://www.mexico.com/politica/dejan-a-conacyt-e-investigacion-cientifica-en-el-errorde-recortes-a-universidades/>accessed 25 July 2019.

National Congress of Brazil (2018), Speech at the lower house of the National Congress of Brazil by Marcelo Moraes, head of the Brazilian National Council for Scientific and Technological Development Centre for Research, (translated from Portuguese) (Brasilia, pubd September 2018) <https://www.camara.leg.br/internet/sitaqweb/TextoHTML.asp>accessed 15 June 2019.

National Library of Congress, Chile (2018), A guide to the Ministry of Science, Technology, Knowledge and Innovation (translated from Spanish) (Santiago; pubd August 2018). 
$<$ https://www.bcn.cl/leyfacil/recurso/ministerio-de-ciencia,-tecnologia,-conocimiento-einnovacion $>$ accessed 25 July 2019.

Noticias Magazine (2018), Scientific policy and crisis: a sudden stop to development (translated from Spanish)(Buenos Aires; pubd online August 2018) $<$ http://noticias.perfil.com/2018/08/12/politica-cientifica-y-crisis-un-frenazo-aldesarrollo/> accessed 2 August 2019.

OECD Publishing (2018), OECD economic surveys, Costa Rica 2018 (Paris; pubd August 2018)

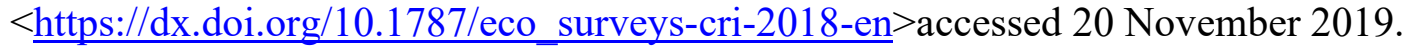

OXFAM (2019), OXFAM: country profile, Brazil (Sao Paulo; pubd online December 1999)<https://www.oxfam.org/en/countries/brazil > accessed 20 December 2019.

Requena, J., and Caputo, C. (2016) 'Pérdida de talento en Venezuela: migración de sus investigadores', Interciencia, 41/7:444, <https://www.redalyc.org/articulo.oa?id=33946267002>

Semanario Universidad Newspaper (2019), Costa Rica and Central America's first cyclotron is being built at the University of Costa Rica (translated from Spanish) (San Jose; pubd April 2019) $<$ https://semanariouniversidad.com/universitarias/primer-ciclotron-de-costa-rica-ycentroamerica-inicio-su-instalacion-en-la-ucr/> accessed 10 October 2019.

Semanario Universidad Newspaper (2018), Clodomiro Picado Institute participated in the creation of antidote against the venom of the black mamba (translated from Spanish) (San Jose; pubd October 2018) <https://semanariouniversidad.com/universitarias/instituto-clodomiropicado-participo-en-creacion-de-antidoto-contra-veneno-de-mamba-negra/> accessed 10 October 2019.

Senacyt (2018), Assessment on the participation of women on science and technology in Panama (translated from Spanish) (Panama City; pubd April 2018) $<$ https://www.senacyt.gob.pa/publicaciones/?publicacion=mujeres-cti $>$ accessed 4 January 4, 2020 .

Spera, S.A., et al. (2016) 'Land-use change affects water recycling in Brazil's last agricultural frontier', Global Change $\quad$ Biology, 22:3405-13 $<$ https://www.ncbi.nlm.nih.gov/pubmed/27028754>.

The Guardian (2019), The World in 2020: Latin America's tumultuous year turns expectations on their head (London; pubd online December 2019), $<$ https://www.theguardian.com/world/2019/dec/30/latin-america-tumultuous-year-2019> accessed 3 January 2020.

The Official Newsletter of the Argentine Republic (2018), Budget: administrative act \# 1605/2018, DA-2018-1605-APN-JGM. budget modification (translated from Spanish) (Buenos Aires; pubd online $\quad$ September 2018 ) $<$ https://www.boletinoficial.gob.ar/\#!DetalleNormaBusquedaAvanzada/191268/20180910>acces sed 3 July 2019. 
The World Bank (2016), Research and development expenditure (\% of GDP)(Washington, DC;

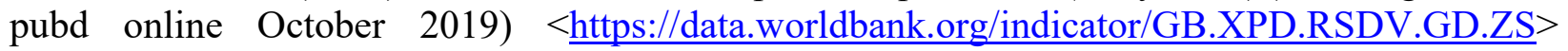
accessed 1 Nov 2019.

UNESCO (2015), UNESCO Institute for Statistics: how much does your country invest in R\&D? (Paris; pubd online December 2015) <http://uis.unesco.org/apps/visualisations/research-anddevelopment-spending/> accessed 10 December 2019.

Acknowledgments: We thank Laura Smales (BioMedEditing, Toronto, Canada) for English editing, and Edward Lempinen for conceptual editing.

Funding: all researchers received kind funding from their local governments and universities. SLV is a member of the Global Young Academy (GYA) and RG and SLV are members of the Sistema Nacional de Investigación (SNI) from SENACYT Panama.

Author contributions: all authors contributed to drafting and revising the manuscript.

Competing interests: the authors declare no competing or conflicting interests.

Data and materials availability: all data are available in the main text. 


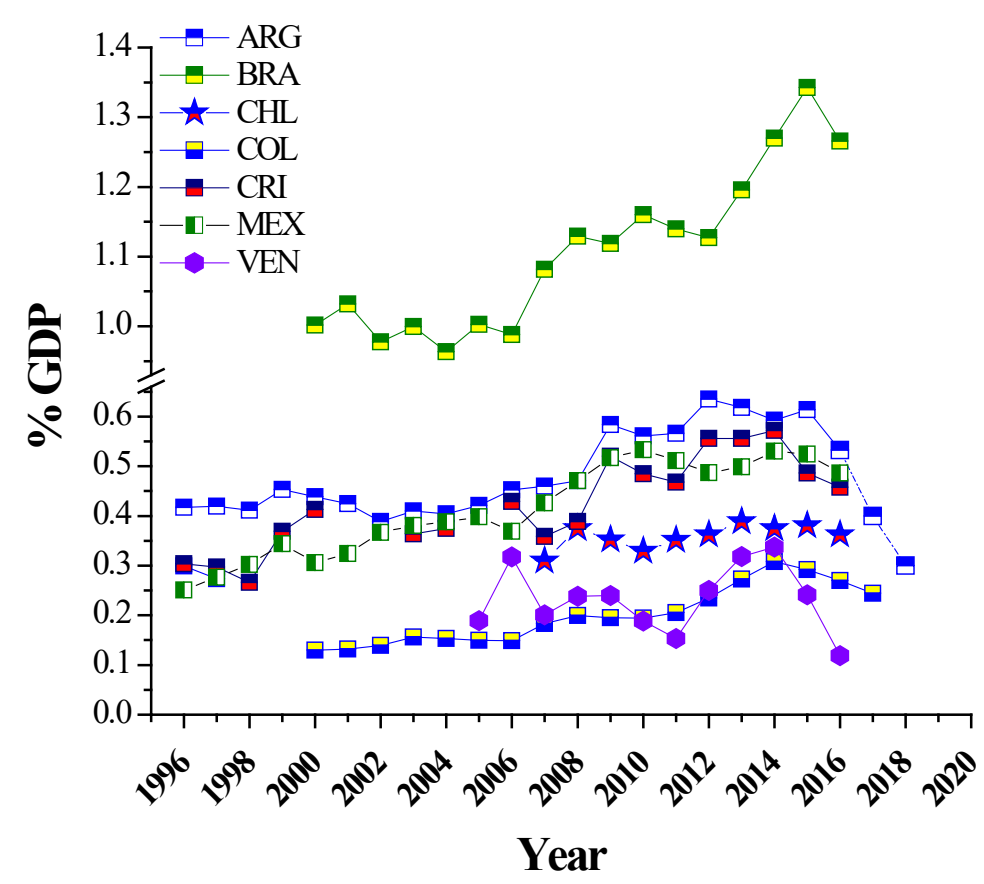

Fig. 1. Investment in science and technology in Latin America (1996-2015, from the World Bank). Blue-dashed line for Argentina represents estimated values according to unofficial data. Since 2016, the Argentinian government has not provided official data.

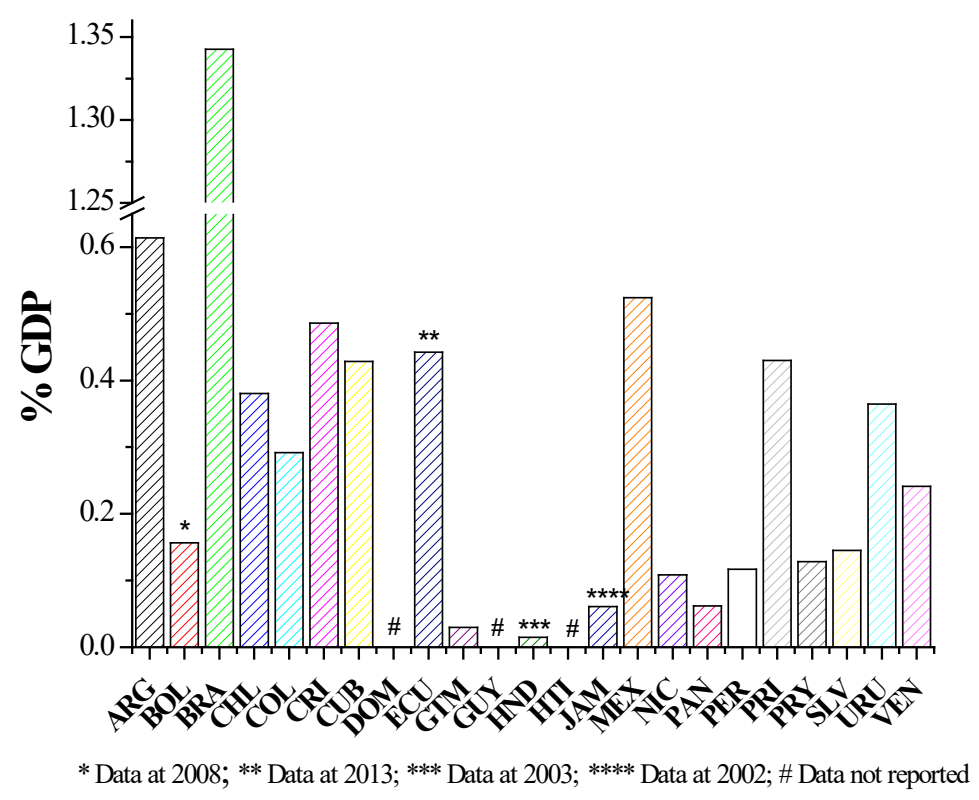

Fig. 2. Investment in science and technology in Latin America and the Caribbean (data as of 2015, from The World Bank, 2016). 


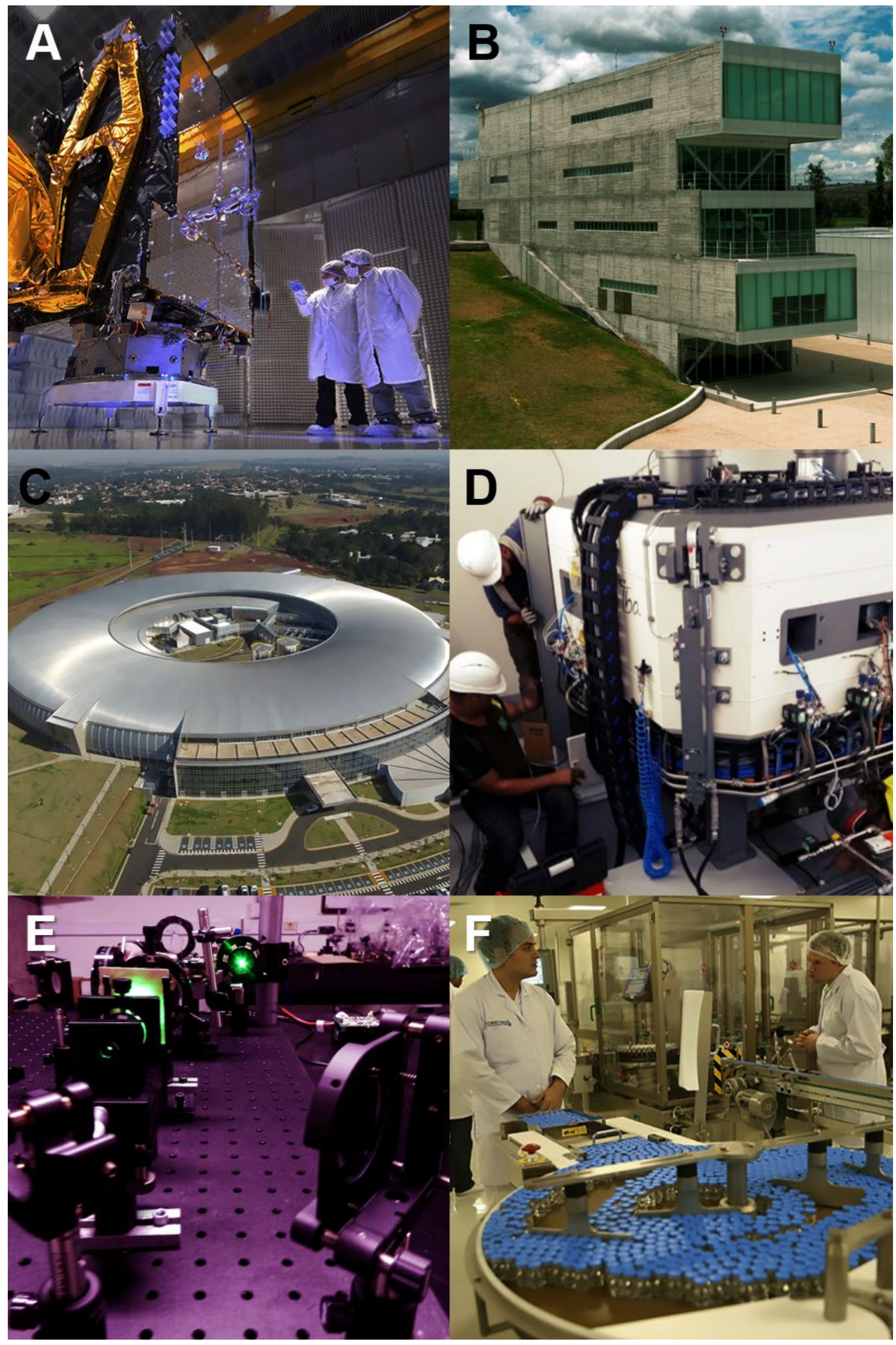

ScienceOpen, 27 January 2020, ID: 10.14293/S2199-1006.1.SOR-.PPBPKUJ.v3 
Fig. 3. Landmark scientific initiatives in Latin America and the Caribbean. A) The Argentinian ARSAT-2 satellite (image courtesy of INVAP Argentina), B) The National Laboratory of Genomics for Biodiversity (Langebio) at Irapuato, Guanajuato State (image courtesy of TEN Arquitectos: LANGEBIO/TEN Arquitectos 2005-2010, Luis Gordoa for TEN Arquitectos), C) The Sirius Synchrotron Light Source in Campinas, Sao Paulo State, Brazil (image courtesy of LNLS/CNPEM, Brazil), D) The Cyclotron at the University of Costa Rica, Rodrigo Facio campus (image courtesy of Dr. Ralph Garcia), E) The Photonics Laboratory at the Antoquia University in Medellin, Colombia (image courtesy of U. of Antioquia), F) The Mechniknov Vaccine Manufacture Plant in Managua, Nicaragua (image courtesy of 19 Digital, Nicaragua). All images were sourced with permission from the respective institutional websites. 